\title{
Effect of intermittent aeration cycle on nutrient removal and microbial community in a fluidized bed reactor-membrane bioreactor combo system
}

\author{
Awoke Guadie ${ }^{\mathrm{a}}$, Siqing Xia ${ }^{\mathrm{b}, *}$, Zhiqiang Zhang ${ }^{\mathrm{b}}$, Jemaneh Zeleke ${ }^{\mathrm{c}}$, Wenshan Guo ${ }^{\mathrm{d}}$, Huu Hao Ngo ${ }^{\mathrm{d}}$, \\ Slawomir W. Hermanowicz ${ }^{\mathrm{e}}$ \\ ${ }^{a}$ UNEP-Tongji Institute of Environment for Sustainable Development, College of Environmental Science and Engineering, Tongji University, Shanghai 200092, China \\ ${ }^{\mathrm{b}}$ State Key Laboratory of Pollution Control and Resource Reuse, College of Environmental Science and Engineering, Tongji University, Shanghai 200092, China \\ ${ }^{\mathrm{c}}$ Department of Microbiology and Microbial Engineering, School of Life Sciences, Fudan University, Shanghai 200433, China \\ ${ }^{\mathrm{d}}$ Center for Technology in Water and Wastewater, School of Civil and Environmental Engineering, University of Technology Sydney, Sydney, NSW 2007, Australia \\ e Department of Civil and Environmental Engineering, University of California, Berkeley, CA 94720, United States
}

\section{H I G H L I G H T S}

- Complete nitrification, high SND and phosphorus recovery were achieved in FBR-MBR.

- The pH in FBR and MBR were found working in harmony.

- The FBR-MBR combo system was a suitable niche for diverse microbial groups.

- Varying intermittent aeration cycle resulted in microbial community shift.

- Proteobacteria, Firmicutes and Bacteroidetes were the dominant phyla identified.

\section{A R T I C L E I N F O}

\section{Article history:}

Received 21 November 2013

Received in revised form 2 January 2014

Accepted 4 January 2014

Available online 21 January 2014

Keywords:

Fluidized bed reactor

Intermittent aeration cycle

Membrane bioreactor

Microbial community

Nutrient removal

\section{G R A P H I C A L A B S T R A C T}

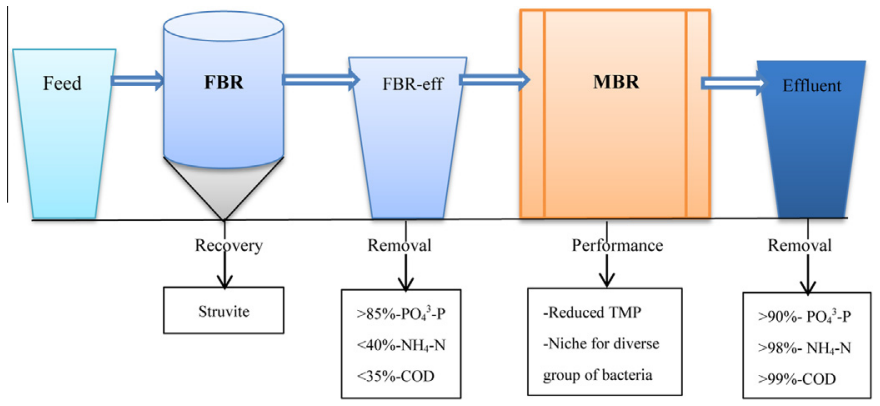

\begin{abstract}
A B S T R A C T
Effect of intermittent aeration cycle (IAC $=15 / 45-60 / 60 \mathrm{~min}$ ) on nutrient removal and microbial community structure was investigated using a novel fluidized bed reactor-membrane bioreactor (FBR-MBR) combo system. FBR alone was found more efficient for removing $\mathrm{PO}_{4}-\mathrm{P}(>85 \%)$ than $\mathrm{NH}_{4}-\mathrm{N}(<40 \%)$ and chemical oxygen demand (COD $<35 \%$ ). However, in the combo system, COD and $\mathrm{NH}_{4}-\mathrm{N}$ removals were almost complete $(>98 \%)$. Efficient nitrification, stable mixed liquor suspended solid and reduced transmembrane pressure was also achieved. Quantitative real-time polymerase chain reaction results of total bacteria 16S rRNA gene copies per $\mathrm{mL}$ of mixed-liquor varied from $(2.48 \pm 0.42) \times 10^{9}$ initial to $(2.74 \pm 0.10) \times 10^{8},(6.27 \pm 0.16) \times 10^{9}$ and $(9.17 \pm 1.78) \times 10^{9}$ for $15 / 45,45 / 15$ and $60 / 60$ min of IACs, respectively. The results of clone library analysis revealed that Proteobacteria (59\%), Firmicutes (12\%) and Bacteroidetes (11\%) were the dominant bacterial group in all samples. Overall, the combo system performs optimum nutrient removal and host stable microbial communities at 45/15 min of IAC.
\end{abstract}

(C) 2014 Elsevier Ltd. All rights reserved.

Abbreviations: AOB, ammonia oxidizing bacteria; COD, chemical oxygen demand; DO, dissolved oxygen; EPS, extracellular polymerase substance; FBR, fluidized bed

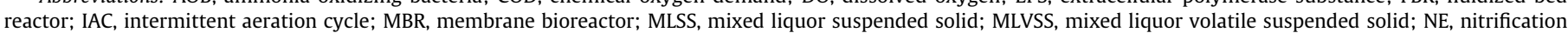

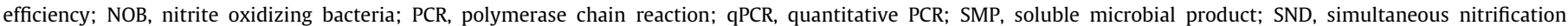
denitrification activity; TMP, transmembrane pressure.

* Corresponding author. Address: P.O. Box 200092, Shanghai, China. Tel.: +86 21 65980440; fax: +86 2165986313.

E-mail address: siqingxia@gmail.com (S. Xia). 


\section{Introduction}

Enrichment of surface water with nutrients (phosphorus and nitrogen) from municipal wastewater treatment discharges is an important water quality concern due to eutrophication. As a result, regulations of the nitrogen and phosphorus contents from wastewater discharge are becoming increasingly more stringent (Ahmed, 2012). Currently, different technologies have been employed to remove these nutrients from wastewater.

Phosphate removal as struvite $\left(\mathrm{MgNH}_{4} \mathrm{PO}_{4} \cdot 6 \mathrm{H}_{2} \mathrm{O}\right)$ using fluidized bed reactors (FBRs) has been widely reported in literatures (Adnan et al., 2003; Le Corre et al., 2007; Liu et al., 2008; Guadie et al., 2013a). Phosphorus recovery as struvite is not only solving the problem of eutrophication but also a sustainable option for replacing the stock phosphate that is being depleted. Phosphate reserve depletion has been estimated less than 100 years (Shu et al., 2006), which drew the attention of the scientific community to focus on alternative strategies to obtain phosphorus (Adnan et al., 2003; Shu et al., 2006; Le Corre et al., 2007). Guadie et al., 2013a designed a novel three cone-inserted FBR that could achieve an efficient phosphorus removal $(>90 \%)$ and high quality struvite recovery at low and high phosphorus concentrations. Using an internal recycling reactor, Liu and his colleagues (Liu et al., 2008) also observed $78 \%$ phosphorus recovery at low phosphorus concentration. Although FBRs are efficient for phosphorus removal and recovery, parallel nitrogen removal as to the discharge limit was not reported. Using FBR for wastewater treatment, Adnan et al. (2003) and Le Corre et al. (2007) observed low nitrogen (<50\%) removal than phosphorus (about $90 \%$ ). Compared to FBR, membrane bioreactor (MBR) has been found a promising nitrogen removal technology as it can enhance growth of bacteria for nitrification and denitrification process (Duan et al., 2009; Guo et al., 2009; Kornboonraksa et al., 2009; Xia et al., 2010).

Nitrification is completed in two steps: ammonium $\left(\mathrm{NH}_{4}\right)$ oxidized into nitrite $\left(\mathrm{NO}_{2}\right)$ by ammonia-oxidizing bacteria (AOB), and $\mathrm{NO}_{2}$ oxidized into nitrate $\left(\mathrm{NO}_{3}\right)$ by nitrite-oxidizing bacteria (NOB) (Ahmed, 2012). Although the stoichiometric showed the requirement of $2 \mathrm{~mol}$ of oxygen (75\% for AOB and 25\% for NOB) per mol of nitrogen to be nitrified (Ruiz et al., 2003), there has been several reports that also showed complete nitrification below $2.0 \mathrm{mg} / \mathrm{L}$ dissolved oxygen (DO) concentration (Bellucci et al., 2011; Wang et al., 2012). Current research efforts on intermittent aeration cycles (IAC) are leading to reduce the level of DO required for nitrification process. During IAC (on/off), the main advantage has been reported the coexistence of nitrifier and denitrifier microbial communities that can perform simultaneous nitrification-denitrification (SND) activities in a single reactor (Third et al., 2003; Rong et al., 2007; Wang et al., 2012). This is due to DO level fluctuation which creates anoxic/oxic microenvironment during "on" and "off" operations (Huang and Ju, 2007; Guadie et al., 2013b). Depending on DO level in the environment, some microbes were reported to shift their electron accepter from oxygen to other preferential sources which in turn leads metabolic activity shift (Feng et al., 2007; Sadaie et al., 2007). Using an online nicotinamide adenine dinucleotide (NAD) fluorescence profiles, Huang and Ju (2007) confirmed that the change of metabolic state observed in the reactor was associated with the shift of electron-accepting mechanisms in the sludge's microbial populations. Sadaie et al. (2007) detected Burkholderiales which could survive under aerobic and anaerobic conditions, based on electron acceptor shift. Ammonia oxidizers (like Nitrosomonas europaea and Nitrosomonas eutropha) were also identified a versatile group of microorganisms found in many natural and engineered ecosystems due to their metabolism flexibility (Sofia et al., 2004; Feng et al., 2007).
Apart from oxygen saving and avoiding two reactor configuration, the advantages of SND such as reduced organic substrate requirements for heterotrophic denitrification, lower biomass production, and self-balanced pH were also reported (Rong et al., 2007; Wang et al., 2012). During nitrification process, hydrogen ion $\left(\mathrm{H}^{+}\right)$released causes a $\mathrm{pH}$ drop in the reactor. However, this drop counter balanced during denitrification process that produces hydroxyl ion $\left(\mathrm{OH}^{-}\right)$(Rong et al., 2007).

Traditionally, microorganisms in wastewater has been analyzed using microscopic observation and culture dependent techniques, although these methods only estimate $1-15 \%$ of the total activated sludge community (Amann et al., 1995). To overcome the limitation of culture dependent methods, recently molecular techniques such as polymerase chain reaction-denaturing gradient gel electrophoresis (PCR-DGGE), fluorescence in situ hybridization, quantitative PCR (qPCR) and 16S rRNA clone library methods have been applied to the detection of microbial community abundance and diversity at various environmental samples (Duan et al., 2009; Wittebolle et al., 2009; Xia et al., 2010; Zhang et al., 2012).

Although a novel combination of MBR with other systems have been evaluated at laboratory and pilot scale for efficient nutrient and organic matter removal (Guo et al., 2009; Kornboonraksa et al., 2009; Guadie et al., 2013b), parallel microbial community analysis data have not been available yet. For instance, Guadie and his colleagues (Guadie et al., 2013b) has been designed a novel FBR-MBR combo system and found a promising reactor performance, however; microbial community information has not been provided. As a result, this study was carried out to support the biochemical data with microbial community analysis. Nutrient removal efficiency (targeting struvite recovery in FBR and nitrogen removal in MBR) and microbial community structures has been investigated by considering IACs as a major factor that has been previously showed significant difference in the reactor performance. The abundance and diversity of the microbial community in the MBR system was investigated using qPCR and clone library construction for total bacteria 16S rRNA gene.

\section{Methods}

\subsection{Wastewater characteristics}

The synthetic wastewater used in this study was prepared according to Xia et al. (2010) with some modifications. It contains $\mathrm{mg} / \mathrm{L}$ : starch (175), glucose (200), peptone (28), urea (64), ammonium chloride (150), potassium dihydrogen phosphate (52.5), magnesium chloride hexahydrate (150) and calcium sulfate dihydrate (50). Trace mineral solution containing (mg/L): $\mathrm{MnCl}_{2} \cdot 4 \mathrm{H}_{2} \mathrm{O}$ (30), $\mathrm{H}_{3} \mathrm{BO}_{3}$ (300), $\mathrm{CoCl}_{2} \cdot 6 \mathrm{H}_{2} \mathrm{O}$ (10), $\mathrm{CuCl}_{2} \cdot 2 \mathrm{H}_{2} \mathrm{O}$ (10), $\mathrm{NiCl}_{2} \cdot 6 \mathrm{H}_{2} \mathrm{O}$ (10), $\mathrm{ZnCl}_{2}$ (100) and $\mathrm{FeSO}_{4} \cdot 7 \mathrm{H}_{2} \mathrm{O}(300)$ were mixed together and $1 \mathrm{~mL} / \mathrm{L}$ was used. Sodium hydroxide $(\mathrm{NaOH}=12.5 \mathrm{mM})$ was also separately prepared for pH adjustment in the FBR (Guadie et al., 2013a).

\subsection{Sludge source}

The reactor was inoculated with mixed liquor that was obtained from a secondary clarifier from Quyang wastewater treatment plant (Shanghai, China). The $\mathrm{pH}$, DO, mixed liquor suspended solid (MLSS) and mixed liquor volatile suspended solid (MLVSS) were measured and their average values were found $6.93 \pm 0.32$, $0.64 \pm 0.41 \mathrm{mg} / \mathrm{L}, 3.62 \pm 0.40 \mathrm{~g} / \mathrm{L}$ and $2.72 \pm 0.23 \mathrm{~g} / \mathrm{L}$, respectively. In order to make the source uniform, the sample was stored at $4{ }^{\circ} \mathrm{C}$ using $20 \%$ glycerol. When the new running conditions were needed, the stored inoculum was acclimatized before feeding to the MBR. 


\subsection{Experimental procedures}

Previously, simultaneous removal of phosphorus and nitrogen from sewage using a novel combo system of FBR-MBR has been studied by constructing a FBR (about $9.5 \mathrm{~L}$ ) and two identical MBRs $(0.3 \mathrm{~m}$ length $\times 0.1 \mathrm{~m}$ width $\times 0.28 \mathrm{~m}$ height $)$ at Tongji University, Shanghai (Guadie et al., 2013b). The same principle and combination also apply in this study (Fig. S1).

Wastewater and $\mathrm{NaOH}$ solution were introduced at the bottom part of the FBR using a peristaltic pump. When the solution was fluidized-up crossing the various areas, chemical reactions were observed in the middle part of the reactor. Through time, the bigger precipitates were settled down at the bottom section. Once sufficient amount of crystals stored at the bottom part of the reactor, they were collected by opening the lower valve. The liquid together with very fine precipitates were flow down from the top part of the FBR to the external recycler. Portion of FBR treated effluent was collected in supernatant tank while the rest was returned back to FBR (Fig. S1).

Effluent from the FBR was continuously treated in MBR system at a constant flow rate of $23 \mathrm{~mL} / \mathrm{min}$. Hollow fiber polyvinylidene fluoride membrane with an area of $200 \mathrm{~cm}^{2}$ and a pore size of $0.1 \mu \mathrm{m}$ was used (Li-tree Company, Suzhou, China). The IAC (on/ off) was made through an air diffuser installed directly beneath the membrane module for supplying oxygen to microbial consortia, mixing the liquor, and scouring the membrane surface. The air flow in MBR was controlled at $8 \mathrm{~L} / \mathrm{h}$. Intermittent filtration with 10 -minutes cycle ( 8 min filtration and 2 min pause) was employed. Membrane fouling was monitored with a transmembrane pressure (TMP) gauge (YN-60, Shanghai Weiken).

In order to investigate the performance of FBR-MBR combo system and microbial communities inside the MBR system, two MBRs $\left(\mathrm{MBR}_{\mathrm{O}}\right.$ and $\mathrm{MBR}_{\mathrm{V}}$ which operated at optimum and variable, respectively) were evaluated under optimum IAC (IAC $)$ (on/off = $45 / 15 \mathrm{~min}$ ) and variable IACs (on/off $=15 / 45,30 / 30,60 / 30$ and $60 / 60 \mathrm{~min}$ ), based on the previous study (Guadie et al., 2013b). The optimum operation conditions for the FBR-MBRs such as $\mathrm{pH}_{\mathrm{FBR}}$, hydraulic retention time (HRT) and flux rate were kept constant 9, $6 \mathrm{~h}$ and $70 \mathrm{~L} /\left(\mathrm{m}^{2} \mathrm{~h}\right.$ ), respectively (Guadie et al., 2013a). Except the sludge used for MLSS analysis, both reactors were operated under no sludge withdrawal condition.

Nitrification efficiencies (NE) and SND activities in the combo system were calculated according to Eq. (1) (Wittebolle et al., 2009) and Eq. (2) (Third et al., 2003), respectively.

$\mathrm{NE}(\%)=100-\frac{\left(\mathrm{NH}_{4}^{+}-\mathrm{N}\right)_{\text {eff }}+\left(\mathrm{NO}_{2}^{-}-\mathrm{N}\right)_{\mathrm{eff}}}{\left(\mathrm{NH}_{4}^{+}-\mathrm{N}\right)_{\text {inf }}} \times 100$

$\mathrm{SND}=\left(1-\frac{\mathrm{C}_{\mathrm{NO}_{x}^{-} \text {produced }}}{\mathrm{C}_{\mathrm{NH}_{4}^{+} \text {-oxidized }}}\right) \times 100 \%$

All experiments were conducted at room temperature (average $25.2 \pm 1.8^{\circ} \mathrm{C}$ ). Summary of the operating conditions are shown in Table 1 .

\subsection{Chemical analytic methods}

For chemical analysis, influent and effluent samples were collected every two days from feed, supernatant and effluent tanks. The constituents of $\mathrm{PO}_{4}-\mathrm{P}, \mathrm{NH}_{4}-\mathrm{N}, \mathrm{NO}_{2}-\mathrm{N}, \mathrm{NO}_{3}-\mathrm{N}, \mathrm{Mg}, \mathrm{Ca}$, MLSS and MLVSS were analyzed according to standard methods (APHA et al., 1998). The $\mathrm{PO}_{4}-\mathrm{P}$ and $\mathrm{NH}_{4}-\mathrm{N}$ were analyzed using UV-visible spectrophotometer (UV-2700, Shimadzu, Japan) while Mg and Ca were measured using flame atomic absorption spectrophotometer (PE-AA400, Perkin Elmer, USA).

Turbidity, DO and $\mathrm{pH}$ were measured using turbidimeter (2100N, HACH, USA), DO meter (HQ4d, HACH USA) and pH meter
(PHS-29A, HACH, USA), respectively. The membrane fouling in the MBR and crystal harvested in the FBR were observed using scanning electron microscope, SEM (XL-30, Philips, Netherlands). Moreover, crystal products were characterized using X-ray diffractometer (XRD).

Sludge characteristics such as soluble microbial product (SMP) and extracellular polymerase substance (EPS) were extracted according to Guadie et al. (2013b). To quantify the EPS and SMP contents of carbohydrate and protein, phenol-sulfuric acid (Dubois et al., 1956) and Lowry (Lowry et al., 1951) methods were used, respectively.

\subsection{Microbial community analyses}

\subsubsection{Sample collection and DNA extraction}

For total genomic DNA extractions, mixed liquor samples were collected at different IACs (on/off $=15 / 45,45 / 15$ and 60/60 $\mathrm{min}$ ). Under $\mathrm{IAC}_{\mathrm{O}}$, more number of samples were collected at day 30 , $60,90,120$ and 150 for both qPCR and clone library construction, aiming for time matter analysis on microbial abundance (Table 1). Forty $\mathrm{mL}$ of mixed liquor was collected and centrifuged for $20 \mathrm{~min}$ at $12,000 \mathrm{~g}$. Then, the supernatants were removed and pellets were resuspended using PBS buffer (mmol/L: $\mathrm{Na}_{2} \mathrm{HPO}_{4} 10 ; \mathrm{KH}_{2} \mathrm{PO}_{4} 2$, $\mathrm{NaCl}$ 137; $\mathrm{KCl} 2.7, \mathrm{pH} 7.4$ ).

Total genomic DNA of each sample was extracted in duplicate using Fast DNA Spin Kit (MP Biomedical, LLC, France) following the manufacturer's protocol, and the duplicate samples were pooled together and stored at $-20^{\circ} \mathrm{C}$ for subsequent assays.

\subsubsection{Quantitative real-time PCR ( $q P C R)$}

The abundance of bacterial communities in the mixed liquor was quantified by SYBR Green I-based qPCR method using $338 \mathrm{f}$ (5'-ACTCCTACGGGAGGCAGC- $3^{\prime}$ ) and 536r (5'-GTATTACCGCGGCK GCTG-3') primers. Triplicate reaction tubes for each sample were used. Each $20 \mu \mathrm{L}$ reaction mixture contained $10 \mu \mathrm{L}$ SYBR ${ }^{\circledR}$ Premix Ex Taq ${ }^{\mathrm{TM}}$ (Takara, Dalian, China), $1 \mu \mathrm{L}$ template DNA (5-10 ng), $0.4 \mu \mathrm{L}(10 \mu \mathrm{M})$ of each primer, $0.4 \mu \mathrm{L}$ of bovine serum albumin (BSA, $0.8 \mu \mathrm{g} / \mu \mathrm{L}$ final concentration), $0.4 \mu \mathrm{L}$ of ROX reference dye $(50 \times)$ and $7.4 \mu \mathrm{L}$ of sterile distilled water. Instead of template DNA, plasmids containing cloned amoA PCR amplicons were used for generating standard curves. The qPCR amplification was carried out in AB7500 qPCR thermocycler (Foster City, USA) using the program $95{ }^{\circ} \mathrm{C}$ for $2 \mathrm{~min}$, followed by 40 cycles of $95^{\circ} \mathrm{C}$ for $30 \mathrm{~s}, 55^{\circ} \mathrm{C}$ for $30 \mathrm{~s}$ and $72{ }^{\circ} \mathrm{C}$ for $30 \mathrm{~s}$. The result was analyzed using Applied Biostatistics 7500 software (version 2.0.5). The amplification efficiency and correlation coefficients $\left(R^{2}\right)$ were $99.76 \%$ and 0.99 , respectively. Melting curves were also analyzed to detect the presence of primer dimers.

\subsubsection{Clone library analysis}

DNA amplification was carried out using 27f (5'-AGA GTTTGATCCTGGCTCAG-3') and 1492r (5'-GGTTACCTTGTTACG ACTT-3') universal bacterial primers. Each $50 \mu \mathrm{L}$ reaction mixture contained $2 \mu \mathrm{L}$ templates DNA (5-10 ng), $25 \mu \mathrm{L}$ Taq PCR Master Mix (Takara, Dalian, China), $2 \mu \mathrm{L}(10 \mu \mathrm{M})$ of each primer, $2 \mu \mathrm{L}$ BSA $(0.8 \mu \mathrm{g} / \mu \mathrm{L}$ final concentration) and $17 \mu \mathrm{L}$ of distilled water. Amplification was carried out using Mycycler (Bio-Rad, USA) under the following conditions: an initial denaturation at $94{ }^{\circ} \mathrm{C}$ for $5 \mathrm{~min}$, followed by 30 cycles of denaturation at $94{ }^{\circ} \mathrm{C}$ for $60 \mathrm{~s}$, annealing at $55^{\circ} \mathrm{C}$ for $60 \mathrm{~s}$ and extension at $72{ }^{\circ} \mathrm{C}$ for $2 \mathrm{~min}$, and a final extension at $72{ }^{\circ} \mathrm{C}$ for $10 \mathrm{~min}$ prior to cooling at $4{ }^{\circ} \mathrm{C}$.

Following PCR amplification, the correctly sized product ( $\sim 1465$ base pairs) was checked by electrophoresis, using $1 \%(\mathrm{w} / \mathrm{v})$ agarose gel stained with ethidium bromide. The PCR products were excised and purified from the gel using a BioDev Gel Extraction System Kit (Beijing, China) following the manufacturer's instructions. The purified PCR products were ligated into a cloning vector 
Table 1

Summary of operating conditions and results.

\begin{tabular}{|c|c|c|c|}
\hline Conditions & Unit & FBR-MBR $_{\mathrm{O}}$ & FBR-MBR $_{V}$ \\
\hline IAC (on/off) & $\min$ & $45 / 15$ & $15 / 45,30 / 30,60 / 30,60 / 60$ \\
\hline Initial flux rate & $\mathrm{L} /\left(\mathrm{m}^{2} \times \mathrm{h}\right)$ & 70 & 70 \\
\hline Hydraulic retention time & h & 6 & 6 \\
\hline Sludge retention time ${ }^{a}$ & d & Without sludge withdraw & Without sludge withdraw \\
\hline \multicolumn{4}{|l|}{ Molecular sampling time ${ }^{b}$} \\
\hline qPCR & d & $0,30,60,90,120,150$ & $0,60,90$ \\
\hline Clone library & d & $0,90,150$ & 0,90 \\
\hline Influent $\mathrm{COD}^{\mathrm{C}}$ & $\mathrm{mg} / \mathrm{L}$ & $250-350$ & $250-350$ \\
\hline Influent $\mathrm{NH}_{4}-\mathrm{N}^{\mathrm{C}}$ & $\mathrm{mg} / \mathrm{L}$ & $40-60$ & $40-60$ \\
\hline Influent $\mathrm{PO}_{4}-\mathrm{P}^{\mathrm{C}}$ & $\mathrm{mg} / \mathrm{L}$ & $10-13$ & $10-13$ \\
\hline Effluent COD & $\mathrm{mg} / \mathrm{L}$ & $<2$ & $1-40$ \\
\hline Effluent $\mathrm{NH}_{4}-\mathrm{N}$ & $\mathrm{mg} / \mathrm{L}$ & $<5$ & $1-15$ \\
\hline Effluent $\mathrm{PO}_{4}-\mathrm{P}$ & $\mathrm{mg} / \mathrm{L}$ & $<1$ & $<1$ \\
\hline Effluent $\mathrm{NO}_{3}-\mathrm{N}$ & $\mathrm{mg} / \mathrm{L}$ & $8.32 \pm 4.6$ & $<30$ \\
\hline Effluent $\mathrm{NO}_{2}-\mathrm{N}$ & $\mathrm{mg} / \mathrm{L}$ & $0.15 \pm 0.04$ & $<1$ \\
\hline MLSS & $\mathrm{mg} / \mathrm{L}$ & $4.6 \pm 0.7$ & $3.0-9.2$ \\
\hline MLVSS & $\mathrm{mg} / \mathrm{L}$ & $4.0 \pm 0.2$ & $3.3-8.4$ \\
\hline Nitrification efficiency & $\%$ & $98.1 \pm 2.2$ & $>85$ \\
\hline SND & $\%$ & $82.8 \pm 11.7$ & $>50$ \\
\hline Turbidity & $\%$ & $>99.8$ & $>99.6$ \\
\hline Temperature & ${ }^{\circ} \mathrm{C}$ & $25.2 \pm 1.8$ & $25.2 \pm 1.8$ \\
\hline
\end{tabular}

a 90-150 days.

b Sample was collected from IACs of 15/45, 45/15 and 60/60 min.

c Raw feed concentration before FBR treatment (which contribute 27-33\%, 37-39\% and 85-90\% removals of $\mathrm{COD} \mathrm{NH}_{4}-\mathrm{N}$ and $\mathrm{PO}_{4}-\mathrm{P}$, respectively).

(PMD ${ }^{18}$-T vector) (Takara, Dalian, China) following manufacturer's protocol. Ligated PCR products were transformed into the competent cells (Escherichia coli, DH5 $\alpha$ ), on ampicillin-supplemented LB medium. About 100 clones from each (total five) samples were used for Sanger sequencing (BGI, Shanghai, China).

\subsubsection{Sequence analysis}

In this study, the mothur software package (Schloss et al., 2009) was used to screen and align sequences, calculate distances, assign sequences to operational taxonomic units (OTUs), and calculate the diversity indices. The forward primers were trimmed from the raw sequences using Bioedit software and then aligned using the SILVA bacteria reference alignment (http://www.arb-silva.de/). Chimeric sequences were screened and removed from the subsequent analysis using the chimera.slayer (version 1.22.0) algorithm (Schloss et al., 2009). Quality sequences were assigned into OTUs. Rarefaction and alpha diversity (Shannon-Wiener diversity index and species richness estimator (Chao1)) indices were analyzed in mothur. All richness and diversity comparisons were made after normalizing the number of sequences in each sample. Sequence information was also used for principal component analysis (PCoA) and Jackknife environment clustering using the UniFrac online tool (http://bmf.colorado.edu/unifrac).

\subsubsection{Nucleotide sequence accession number}

Sequences obtained in this study were submitted to the National Center for Biotechnology Information (http://www.ncbi.nlm.nih. gov/) under accession number KF830278-830660.

\section{Results and discussion}

\subsection{Effect of intermittent aeration cycle on FBR-MBR combo} performance

\subsubsection{Effect of intermittent aeration on $\mathrm{pH}$}

As the $\mathrm{pH}$ value of $8-10$ was recommended as the operative range for quality struvite recovery in the FBR (Le Corre et al., 2007; Guadie et al., 2013a), the feed pH (6.5 \pm 0.7$)$ was adjusted with $\mathrm{NaOH}$ solution to an alkaline range $(\mathrm{pH} \geqslant 9)$. After FBR treatment, the solution $\mathrm{pH}$ was $8.8 \pm 0.5$ in the supernatant tank, which was lower than the $\mathrm{pH}$ in the FBR $(p=0.001, n=72)$ (Fig. 1). Throughout this study, by using Student's $t$-test a value of $p<0.05$ was considered statistically significant.

Crystal (struvite) formation observed at the middle part of the FBR resulted in a $\mathrm{pH}$ drop (produce $\mathrm{H}^{+}$) in the system Eq. (3). Using SEM and XRD, harvested crystals were analyzed and confirmed pure struvite (Fig. S2). Struvite recovery in the combo system can be viewed as a unique feature of this study which makes phosphorus management more sustainable (by avoid eutrophication risk and resource depletion). Studies showed that struvite is a slow released fertilizer which can be applied directly to plant growth (Shu et al., 2006; Liu et al., 2008).

$$
\begin{aligned}
& \mathrm{Mg}^{2+}+\mathrm{NH}_{4}^{+}+\mathrm{H}_{n} \mathrm{PO}_{4}^{n-3}+6 \mathrm{H}_{2} \mathrm{O} \\
& \quad \rightarrow \mathrm{MgNH}_{4} \mathrm{PO}_{4} \cdot 6 \mathrm{H}_{2} \mathrm{O}+\mathrm{nH}^{+}, n=0,1 \text { and } 2
\end{aligned}
$$

Microorganisms are very vulnerable and sensitive to $\mathrm{pH}$ value of the wastewater. Since pH lower than 6.5 or higher than 9.0 could inhibit nitrification completely, the preferential ranges for $\mathrm{AOB}$ and NOB are about 7.5-8.5 and 6.5-7.5, respectively (Ruiz et al., 2003; Campos et al., 2007; Rong et al., 2007). Generally, pH adjustment with $\mathrm{NaHCO}_{3}$ needs to be performed during MBR operation. However, in this study, it was found that the combo system was confirmed working in harmony without any $\mathrm{pH}$ adjustment, because struvite formation and IAC played a significant $\mathrm{pH}$ modification in the system. For example, when $\mathrm{pH}$ was measured in $\mathrm{MBR}_{\mathrm{O}}$ under non-aeration cycle (off) and aeration cycle (on), results were statistically different $(p=6.48 \mathrm{E}-11<0.05)$ with $\mathrm{pH}$ value of $7.8 \pm 0.5$ and $7.2 \pm 0.4$, respectively (Fig. 1 ). The same significant $\mathrm{pH}$ difference was observed in $\mathrm{MBR}_{\mathrm{V}}$ system (7.1 \pm 0.7 for "on" cycle and $7.4 \pm 0.8$ for "off" cycle, $p=1.06 \mathrm{E}-05)$. This could be due to the microbial consortia catabolic activities on starch, glucose, urea and peptone added as a feed which usually converts to simple organic acids and decreased the $\mathrm{pH}$ value. The final effluent $\mathrm{pH}$ for $\mathrm{MBR}_{\mathrm{O}}$ and $\mathrm{MBR}_{\mathrm{V}}$ were $7.4 \pm 0.5$ and $7.2 \pm 0.6$, respectively, which was in the range of $\mathrm{pH}$ discharge limit set by many countries (6-9). 


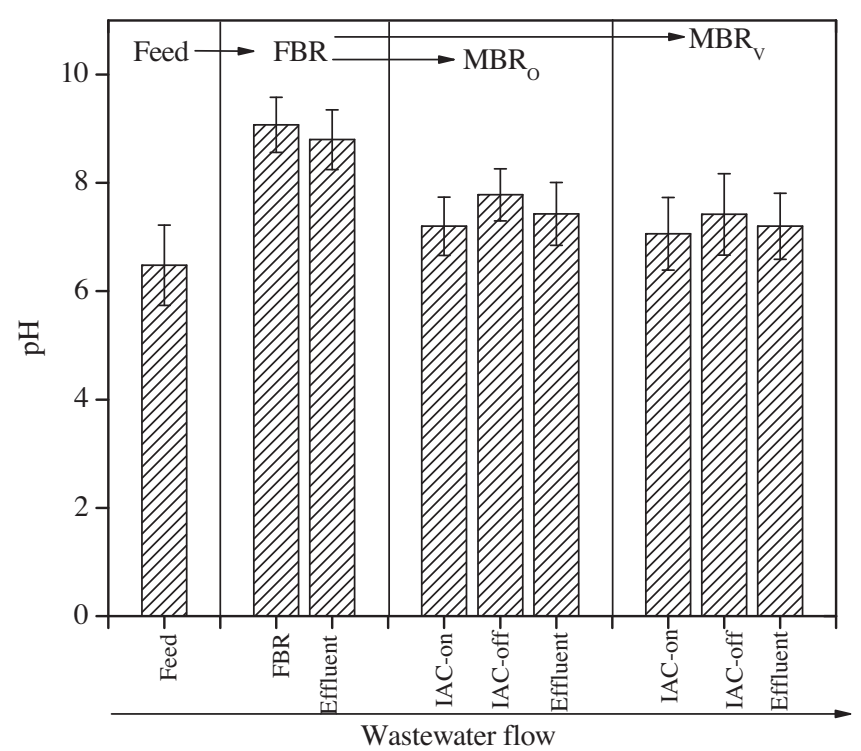

Fig. 1. The $\mathrm{pH}$ values $(n=72)$ of feed, $F B R, M B R$ and effluent that operate at optimum $\left(\mathrm{MBR}_{\mathrm{O}}\right)$ and variable $\left(\mathrm{MBR}_{\mathrm{V}}\right)$ conditions. IAC-on and IAC-off is used to indicate $\mathrm{pH}$ measurements carried out in the MBR under air pump working and pausing periods, respectively. The MBR effluent $\mathrm{pH}$ was the combined result that flows during "on" and "off" cycles.

\subsubsection{Effect of intermittent aeration on DO concentration and removal efficiency}

As shown in Table 2, under optimal operating condition (FBR$\mathrm{MBR}_{\mathrm{O}}$ ), the average DO concentration was $3.6 \pm 0.6 \mathrm{mg} / \mathrm{L}$ for aeration cycle and $1.5 \pm 0.6 \mathrm{mg} / \mathrm{L}$ for non-aeration cycle, which was statistically significant $(p<0.05)$. When the FBR-MBR combo system $_{V}$ works under different IACs, the average DO concentrations varied from 0.8 to $6.1 \mathrm{mg} / \mathrm{L}$ for aeration cycle and 0.3 to $3.4 \mathrm{mg} / \mathrm{L}$ for non-aeration cycle $(p<0.05)$ (Table 2$)$.

Prior treatment of the raw wastewater with FBR system modified the wastewater characteristics and improved the removal efficiency in MBR system. The removal efficiency of $\mathrm{PO}_{4}-\mathrm{P}$ in $\mathrm{FBR}$, and COD and $\mathrm{NH}_{4}-\mathrm{N}$ in the MBR was significant (Table 2). When FBR$\mathrm{MBR}_{\mathrm{O}}$ operated at $\mathrm{IAC}_{\mathrm{O}}$, the $\mathrm{COD}, \mathrm{NH}_{4}-\mathrm{N}$ and $\mathrm{PO}_{4}-\mathrm{P}$ removals were $99.4 \pm 0.6,98.7 \pm 2.1$ and $92.3 \pm 4.1$, respectively. Varying the IAC in the combo system (FBR-MBR $)$ did not show apparent difference in phosphorus removal (91-95\%). For instance, at IACs of 60/60 and $15 / 45 \mathrm{~min}$, the phosphorus removal efficiency showed statistically insignificant change $(p=0.83)$. However, the variation was considerably significant for $\mathrm{NH}_{4}-\mathrm{N}(64-99 \%, p=0.002)$ and $\mathrm{COD}$ (83-99.5\%, $p=0.003$ ) removals. At IAC of $15 / 45 \mathrm{~min}$, the level of DO was between 0.3 and $0.8 \mathrm{mg} / \mathrm{L}$, which showed significant reduction of $\mathrm{NH}_{4}-\mathrm{N}(\sim 35 \%)$ and COD $(\sim 15 \%)$ removal efficiency

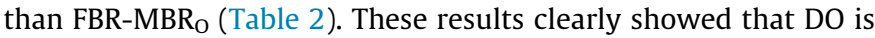
an important factor for microbial degradation of $\mathrm{NH}_{4}-\mathrm{N}$ and COD removal than phosphorus, particularly AOB showed more response to the low DO tension. Studies showed that nitrification processes by nitrifiers are more sensitive to environmental conditions (oxygen, substrate, $\mathrm{pH}$ and availability of electron acceptors) than carbon oxidation by heterotrophs (Sofia et al., 2004; Campos et al., 2007).

Although extending the aeration cycle higher than $45 \mathrm{~min}$ (e.g. IAC $=60 / 60 \mathrm{~min}$ ) help to assure more efficient $\mathrm{NH}_{4}-\mathrm{N}$ and COD removal, the condition was found disturbing the sludge floc structure developed in the MBR system. Since there was no apparent difference in $\operatorname{COD}(p=0.640)$ and $\mathrm{NH}_{4}-\mathrm{N}(p=0.738)$ removals at $60 / 60$ and $45 / 15$ min IACs, the later operation has been considered as optimum, based on energy saving.

As shown in Fig. 2, microbes governing the subsequent conversion of $\mathrm{NH}_{4}-\mathrm{N}$ to $\mathrm{NO}_{2}-\mathrm{N}$ and then $\mathrm{NO}_{3}-\mathrm{N}$ initially seemed more quiescent than COD degrading microbes. However, after 1 month operation, the sludge became active and showed a significant reduction of $\mathrm{NH}_{4}-\mathrm{N}$. Throughout the entire experimental process in FBR-MBR ${ }_{\mathrm{O}}$, the initial $\mathrm{NH}_{4}-\mathrm{N}$ and COD concentrations varied from $40-60(50.7 \pm 4.0) \mathrm{mg} / \mathrm{L}$ to $250-350(291.03 \pm 27.0) \mathrm{mg} / \mathrm{L}$, respectively (Fig. 2a). The average $\mathrm{NH}_{4}-\mathrm{N}$ and COD effluent concentrations were also found less than 5 and $2 \mathrm{mg} / \mathrm{L}$, respectively. The $\mathrm{NO}_{2}-\mathrm{N}$ and $\mathrm{NO}_{3}-\mathrm{N}$ in the FBR-MBR $\mathrm{O}_{0}$ system was $0.06-0.20$ $(0.15 \pm 0.04) \mathrm{mg} / \mathrm{L}$ and $4.0-25.0(8.32 \pm 4.6) \mathrm{mg} / \mathrm{L}$, respectively (Table 1). After 1 month operation, respectively the NE and SND efficiency in FBR-MBR ${ }_{0}$ were $92-99 \%(98.1 \pm 2.2 \%)$ and $75-95 \%$ $(82.8 \pm 11.7 \%)$ (Table 1$)$, suggesting that the combo system provides suitable environmental niche for $\mathrm{AOB}$ and NOB communities. When the system operated at $\mathrm{IAC}_{O}$ and $60 \mathrm{~min}$ "on" aeration cycle, DO concentration was not the limiting factor for nitrification process (Table 2). Generally, DO concentrations greater than $2 \mathrm{mg} / \mathrm{L}$ is essential to maintain complete nitrification in biological wastewater treatment plants (Ruiz et al., 2003; Ahmed, 2012; Wang et al., 2012).

The nitrogen and COD removals were consistent with biomass growth in the bioreactor $\left(\mathrm{MBR}_{\mathrm{O}}\right)$. The MLSS and MLVSS concentrations varied from 3.4-5.2 $(4.6 \pm 0.7) \mathrm{g} / \mathrm{L}$ to $2.7-4.6(4.0 \pm 0.2) \mathrm{g} / \mathrm{L}$, respectively (Fig. 2b). The ratio of MLVSS to MLSS concentration in the MBR system was found to be varying from 0.75 to 0.92 $(0.89 \pm 0.03)$. The ratio was found almost constant and higher after 30 days of reactor operation.

\subsubsection{Effect of intermittent aeration on membrane fouling}

To illustrate membrane fouling, EPS and SMP concentrations were quantified as fractions of carbohydrates and proteins. As shown in Fig. 3a, relatively higher EPS protein $\left(\mathrm{EPS}_{\mathrm{P}}\right)$ was observed at each intermittent cycle, but the difference was insignificant. The same insignificant difference was also observed on SMP protein and carbohydrate $\left(\mathrm{SMP}_{\mathrm{P}}\right.$ and $\left.\mathrm{SMP}_{\mathrm{C}}\right)$. Nevertheless, the EPS carbohydrate $\left(E P S_{C}\right)$ was significantly varied from 20 to $80 \mathrm{mg} / \mathrm{L}$, depending on IACs (Fig. 3a). The observed $\mathrm{EPS}_{\mathrm{C}}$ concentrations of $47.2 \pm 1.7 \mathrm{mg} / \mathrm{L}$ for IAC $30 / 30 \mathrm{~min}$ and $78.4 \pm 2.4 \mathrm{mg} / \mathrm{L}$ for IAC $15 / 45$ min were probably the main cause of TMP development (Fig. 3b) that led to fast membrane fouling. The TMP was higher $(>50 \mathrm{kPa})$ at lower IAC $(15 / 45 \mathrm{~min})$ than extended IACs $(\mathrm{TMP}<10 \mathrm{kPa})$ (Fig. 3b). At lower aeration cycle (IAC $=$ $15 / 45 \mathrm{~min}$ ), the level of DO was $<1 \mathrm{mg} / \mathrm{L}$ (Table 2 ) which resulted

Table 2

Effect of intermittent aeration cycles on DO concentration (mg/L) and removal efficiency (\%) in the combo system.

\begin{tabular}{|c|c|c|c|c|c|c|c|c|}
\hline \multirow[t]{2}{*}{ IAC (on/off) (min) } & \multicolumn{2}{|c|}{$\mathrm{DO}(\mathrm{mg} / \mathrm{L})$} & \multicolumn{3}{|c|}{ FBR } & \multicolumn{3}{|c|}{ FBR-MBR } \\
\hline & On & Off & COD & $\mathrm{NH}_{4}-\mathrm{N}$ & $\mathrm{PO}_{4}-\mathrm{P}$ & COD & $\mathrm{NH}_{4}-\mathrm{N}$ & $\mathrm{PO}_{4}-\mathrm{P}$ \\
\hline $60 / 60$ & $6.1 \pm 0.5$ & $3.4 \pm 0.2$ & $27.4 \pm 5.5$ & $39.0 \pm 6.6$ & $89.1 \pm 2.0$ & $99.5 \pm 0.5$ & $99.1 \pm 0.8$ & $91.0 \pm 1.8$ \\
\hline $60 / 30$ & $4.4 \pm 0.7$ & $1.6 \pm 0.5$ & $31.7 \pm 3.8$ & $38.2 \pm 3.2$ & $88.2 \pm 2.7$ & $99.0 \pm 1.0$ & $99.0 \pm 0.5$ & $94.8 \pm 1.7$ \\
\hline $45 / 15^{\mathrm{a}}$ & $3.6 \pm 0.6$ & $1.5 \pm 0.6$ & $28.8 \pm 5.8$ & $37.1 \pm 10.1$ & $85.4 \pm 4.7$ & $99.4 \pm 0.6$ & $98.7 \pm 2.1$ & $92.3 \pm 4.1$ \\
\hline $30 / 30$ & $1.5 \pm 0.3$ & $0.6 \pm 0.3$ & $28.2 \pm 8.3$ & $38.6 \pm 8.1$ & $90.1 \pm 1.0$ & $88.2 \pm 2.6$ & $76.7 \pm 4.0$ & $93.7 \pm 1.5$ \\
\hline $15 / 45$ & $0.8 \pm 0.2$ & $0.3 \pm 0.2$ & $32.7 \pm 4.4$ & $37.7 \pm 5.4$ & $86.5 \pm 3.8$ & $83.3 \pm 7.3$ & $64.3 \pm 9.0$ & $92.1 \pm 1.3$ \\
\hline
\end{tabular}

a Results obtained from $\mathrm{IAC}_{\mathrm{O}}$. 

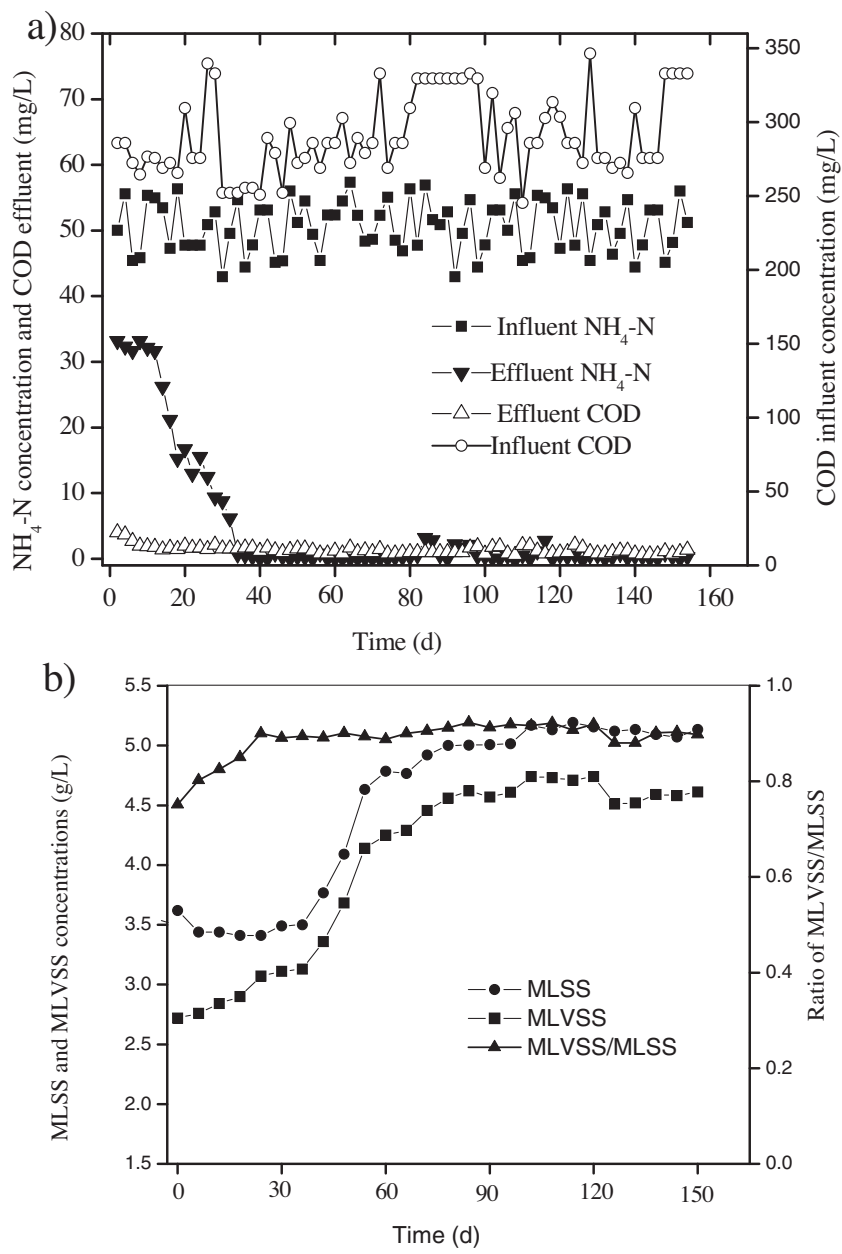

Fig. 2. Performance of FBR-MBR $\mathrm{O}_{\mathrm{O}}$ combo system through time (a) $\mathrm{NH}_{4}-\mathrm{N}$ and COD concentration (b) MLSS and MLVSS concentration.

in low biological organic degradation. This condition could create unfavorable environment for key microbial consortia that play a significant role in reducing the incoming organic feed and polymeric byproducts (Dionisi et al., 2003; Xia et al., 2010). In the absence of DO tension (IACs $=45 / 15,60 / 30$ and $60 / 60 \mathrm{~min}$ ), these microorganisms might be well acclimatized and able to reduce the membrane foulants (Fig. 3a). This might be supported by higher qPCR and Proteobacteria results observed in Section 3.2 (IACs $=45 / 15$ and 60/60 $\mathrm{min}$ ). Previous studies showed that under favorable conditions, microorganisms could grow well and be capable of consuming more macromolecules such carbohydrate and protein as substrates leading to reduce membrane fouling rate (Masse et al., 2006).

The low MLSS concentration observed in all operations ( $4<$ MLSS $<10 \mathrm{~g} / \mathrm{L}$ ) suggested that MLSS concentration in the system has not been positively associated with TMP values (Fig. 3b). This could be due to inorganic components (like phosphate) were precipitated as struvite in the FBR and did not accumulate in the MBR system. This result is consistent with the previous study that MLSS concentration (3.0-8.5 mg/L) was not the main cause of TMP raise/membrane fouling (Guadie et al., 2013b).

\subsection{Microbial community analyses}

In this study, attempts have been made to support the molecular data with the biochemical results. Total bacterial abundance and diversity were analyzed using qPCR and clone library construction.
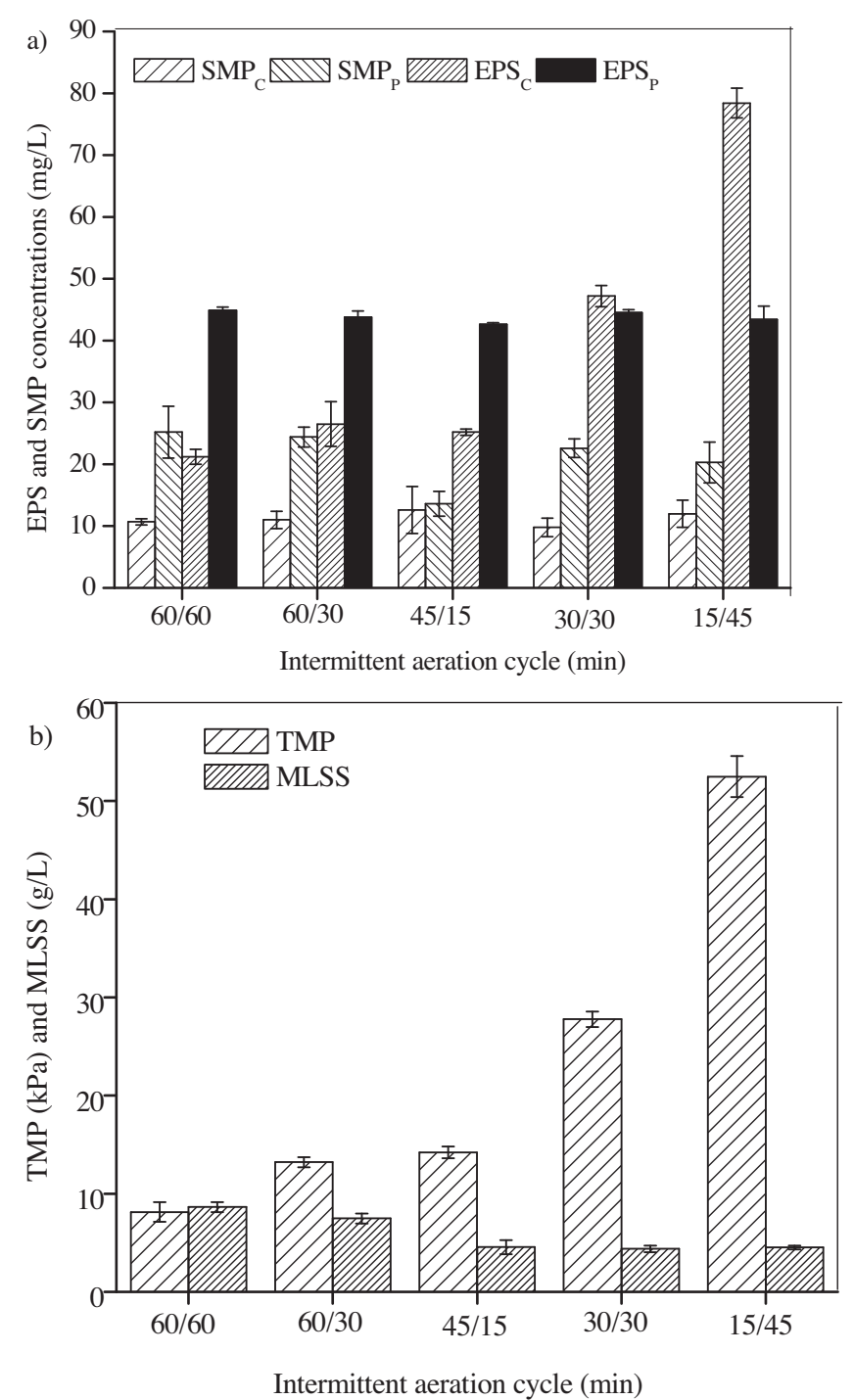

Fig. 3. Effect of different IAC (a) soluble microbial product (SMP) and extracellular polymerase substance (b) Transmembrane pressure (TMP) and mixed liquor suspended solids (MLSS).

\subsubsection{Abundance of total bacteria}

Real-time qPCR was used to examine the dynamics of the total bacterial 16S rRNA gene copies in the MBRs that were operated at different IACs (Fig. 4). Under $I_{A C}$, the abundance of bacterial $16 \mathrm{~S}$ rRNA gene copies showed substantial amount of fluctuation over the course of time. The average copy numbers per $\mathrm{mL}$ of mixedliquor increased from $(4.13 \pm 0.10) \times 10^{9}$ to $(6.27 \pm 0.16) \times 10^{9}$ (sample 2-6) (Fig. 4). Compared to the initial inoculum $(2.48 \pm 0.42) \times 10^{9}$ gene copies $\left./ \mathrm{mL}\right)$, all samples showed significant difference $(p<0.05)$. However, there was no significant difference between samples collected at day 60 (sample 3) and day 150 (sample 6$)(p=0.139)$. This result is consistent with the chemical analysis. As stated earlier, throughout the entered study period complete nitrification was achieved after 1 month operation, suggesting that the nitrifier communities may be more adapted through time in the combo system and played a significant role for modifying the wastewater characteristic and maintain stable reactor performance. This result is also consistent with other studies. According to Duan et al. (2009), the bacterial numbers showed dynamic changes in the first 20 days, and stabilized after that time. Dionisi and his colleagues (Dionisi et al., 2003) also stated that due to slow grower bacteria biomass increase (i.e. Nitrospira cells), 


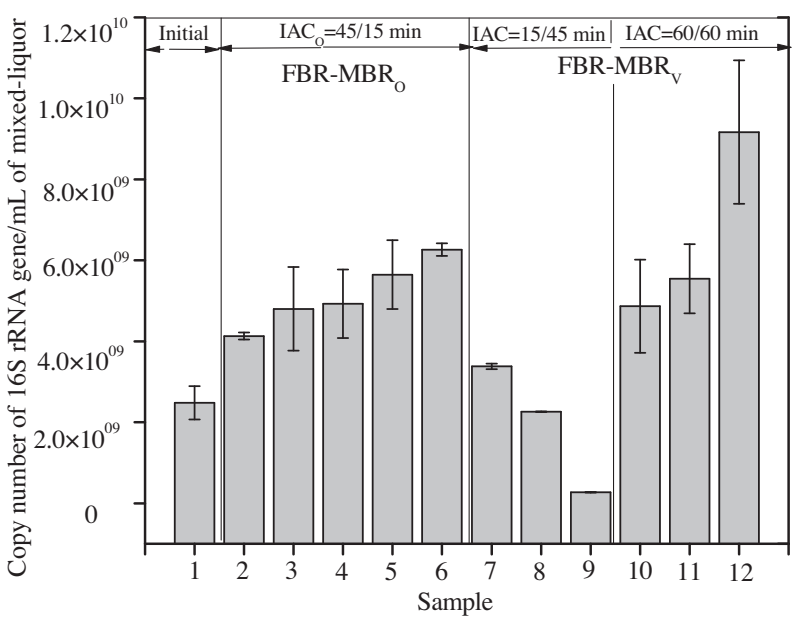

Fig. 4. Total bacterial copy numbers of $16 \mathrm{~S}$ rRNA gene per $\mathrm{mL}$ of mixed-liquor for initial (sample 1), 45/15 min (sample 2, 3, 4, 5 and 6 collected at day 30, 60, 90, 120 and 150 , respectively), 15/45 min (sample 7, 8 and 9 collected at day 30,60 and 90) and $60 / 60 \mathrm{~min}$ (sample 10,11 and 12 collected at day 30,60 and 90) aeration cycles for FBR-MBR combo systems as revealed by the SYBR Green I based qPCR method.

complete nitrification has been observed at 20 day sludge age sample than 2, 5 and 10 days of reactor operation.

Samples (7-12) were also collected from FBR-MBR $\mathrm{V}_{\mathrm{V}}$ combo system at day 30, 60 and 90 from short (IAC $=15 / 45 \mathrm{~min}$ ) and extended aeration cycle operations (IAC $=60 / 60 \mathrm{~min}$ ). The 16S rRNA gene copy numbers per $\mathrm{mL}$ of mixed-liquor were significantly reduced from $(3.38 \pm 0.07) \times 10^{9}$ to $(2.74 \pm 0.10) \times 10^{8}$ (samples $7-9, p=0.0002$ ), when the combo system was operated at short aeration cycle (Fig. 4). The results were also consistent with the low $\mathrm{NH}_{4}-\mathrm{N}$ and COD removal efficiencies observed at short aeration cycle (64\% and $83 \%$, respectively) (Table 2$)$. On the contrary, samples (10-12) that was operated at $60 / 60$ min of IAC showed increase bacterial gene abundance from $(4.87 \pm 1.15) \times 10^{9}$ to $(9.17 \pm 1.78) \times 10^{9}$ per $\mathrm{mL}$ of mixed-liquor (Fig. 4$)$. Since the bacterial abundance has no apparent difference between 45/15 and $60 / 60$ min of IACs (e.g., $p=0.120$ for sample 6 and 12), optimizing the combo system to work at $45 / 15$ min aeration cycle could be more sustainable, which is consistent with the chemical analysis.

\subsubsection{Microbial community composition and diversity}

After chimeric sequences are removed $(<1 \%)$, quality sequences were affiliated to different OTUs. As shown in Table 3, a total of 383 and 375 OTUs were observed at 97\% and 95\% similarity cutoff, respectively. The initial OTUs (72) were higher than the OTUs (66) obtained at $60 / 60$ min of IAC operation. Although further efforts needed to evaluate the microbial biodiversity in the reactor with other molecular techniques, this result may be a clue that the initial microbial inoculum (Quyang wastewater treatment plant) has been affected by the DO difference created in the MBR treatment system (IAC $=60 / 60 \mathrm{~min})$. Moreover, operations at IACs of 15/45 and 45/15 min showed higher OTUs; particularly the later operation showed relatively higher number of OTUs (81-84). At $\mathrm{IAC}_{\mathrm{O}}$, extending the growth period from 90 to 150 days showed almost the same number of OTUs and Shannon-Wiener diversity, which are consistent to qPCR results. However, Chao1 showed higher number at day 150 than 90, indicating extending the growth period could favor species richness than diversity (Table 3 ) (Dionisi et al., 2003; Sofia et al., 2004).

Shannon-Wiener index (higher numbers imply higher diversity) was found between 4.19-4.43, regardless of IAC and cutoff values (Table 3). This result was found comparable to other similar Shannon-Wiener diversity index reports $(0.91-3.38)$ on wastewater treatment activated sludge (Xia et al., 2010; Duan et al., 2009). The co-existence of more diverse microbial populations in the combo system might offer a wide range of microbial metabolic diversity which could play efficient wastewater removal activity (Table 2). Although microbial diversity observed in this study seemed higher, yet the current sampling effort might be inadequate to quantify all the microbial diversity found in the combo system. The linearity of the rarefaction curve (95\% and 97\%) suggested that diversity becomes more in the combo with an increasing number of sample sequences (Fig. S3).

Samples from the different IACs were clustered using PCoA and environment clustering through weighted normalized UniFrac analysis (Fig. 5). Out of the total 54\% variance observed, $29.12 \%$ and $24.89 \%$ variations were explained by the first (P1) and second (P2) coordinates, respectively (Fig. 5a). The initial DO where the microbial inoculum first collected $\left(0.64 \mathrm{mg} \mathrm{O}_{2} / \mathrm{L}\right)$ and IAC of $15 / 45 \mathrm{~min}\left(0.30-0.80 \mathrm{mg} \mathrm{O}_{2} / \mathrm{L}\right)$ were almost found in the same range, which can group the two environments on the left side of the first axis. Sample 2 and $3\left(\mathrm{IAC}_{\mathrm{O}}\right)$ and sample $5(\mathrm{IAC}=60 / 60 \mathrm{~min})$ were also clustered on the right side of the first axis. However, using DO as final electron acceptor, sample 2 (day 90) and 3 (day 150) that was operated at the same $\mathrm{IAC}_{\mathrm{O}}$ did not cluster on the same coordinate, instead the former clustered with sample 5 (day 90) as a function of growth period. This result indicates the insignificant difference in DO concentration and removal efficiency observed at extended IACs (Table 2). Normally, community clustering is caused by only one environmental factor at a time (Lozupone and Knight, 2005). This is consistent with the current study in which either DO level or growth period at a time cause for clustering. The Jackknife environment cluster analysis (Fig. 5b) was also consistent with PCoA.

The phylogenetic classification using the SILVA taxonomy reference file at $80 \%$ threshold value showed that all of the sequences were grouped into 14 known bacterial phyla and a small proportion to unclassified sequences (about 5\%) (Fig. 6a). In the entire operation, Proteobacteria (59\%) followed by Firmicutes (12\%) and Bacteroidetes (11\%) were the most dominant phyla which together comprised $82 \%$ of the total sequences. The phyla Actinobacteria, Chloroflexi, Nitrospirae and Planctomycetes were also detected at various operations (Fig. 6a). Interestingly, the phylum Nitrospirae which comprise a known NOB group was not detected at IAC of $15 / 45 \mathrm{~min}$, but identified at IACs of 45/15 min and 60/60 min. This

Table 3

Characteristic and diversity estimators for 16S rRNA gene clone libraries derived from initial and experimental samples.

\begin{tabular}{|c|c|c|c|c|c|c|c|}
\hline \multirow[t]{2}{*}{ IAC (on/off) (min) } & \multirow[t]{2}{*}{ Time (day) } & \multicolumn{3}{|c|}{0.03 (97\% similarity) } & \multicolumn{3}{|c|}{0.05 (95\% similarity) } \\
\hline & & OTUs & Chao1 & Shannon & OTUs & Chao1 & Shannon \\
\hline- & 0 & 72 & 2628 & 4.28 & 71 & 1279 & 4.26 \\
\hline $45 / 15$ & 90 & 83 & 1744 & 4.41 & 81 & 832 & 4.38 \\
\hline $45 / 15$ & 150 & 84 & 3570 & 4.43 & 83 & 1744 & 4.41 \\
\hline $15 / 45$ & 90 & 78 & 1541 & 4.35 & 74 & 678 & 4.28 \\
\hline $60 / 60$ & 90 & 66 & 2211 & 4.19 & 66 & 2211 & 4.19 \\
\hline
\end{tabular}

IAC = intermittent aeration cycle, OTUs = operational taxonomic units, - = IAC operation not considered (initial sample). 


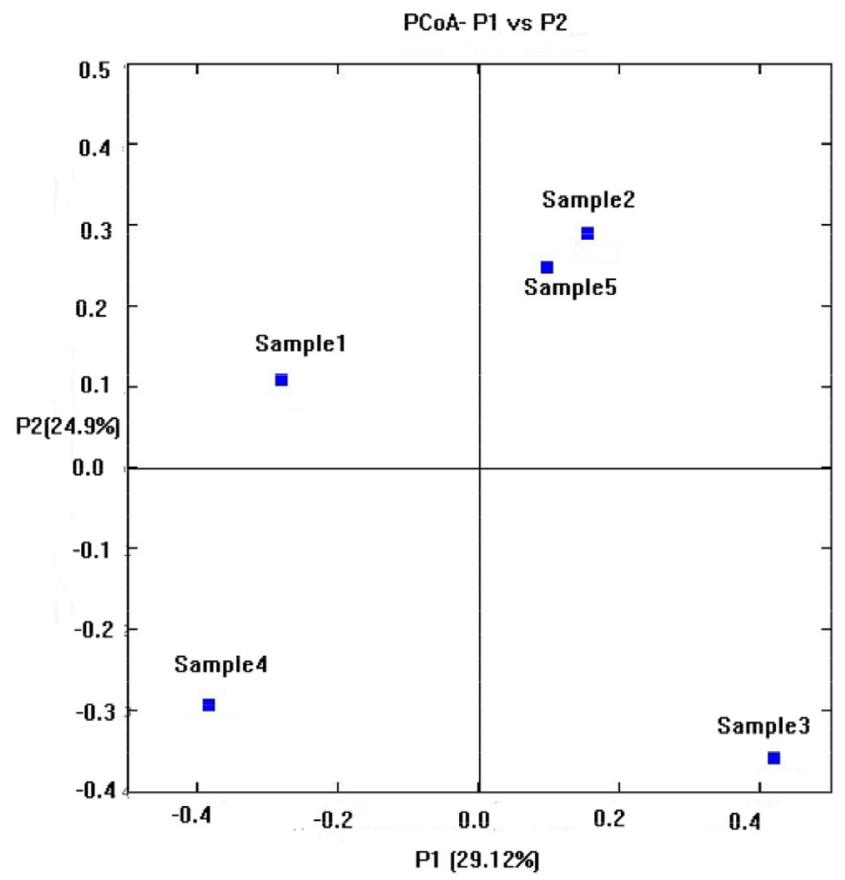

a) Principal coordinate analyses ( $\mathrm{PCoA})$

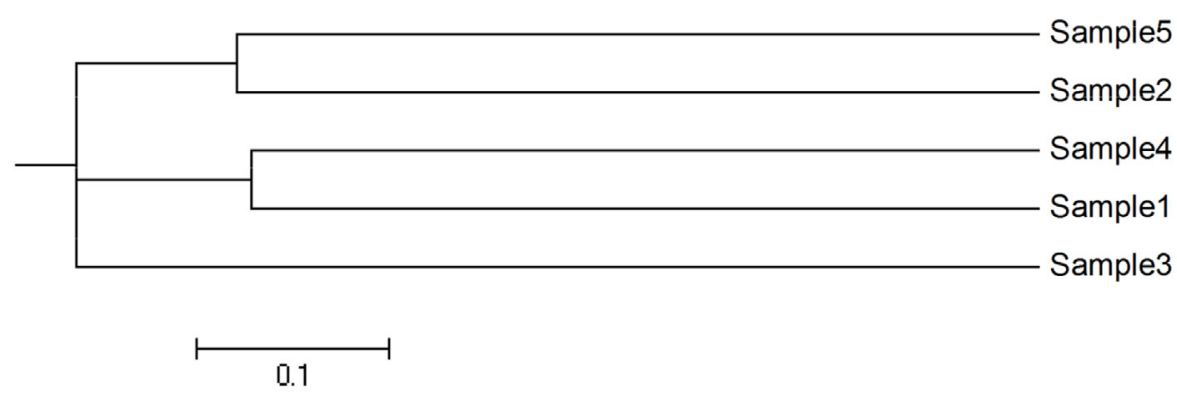

b) Jackknife

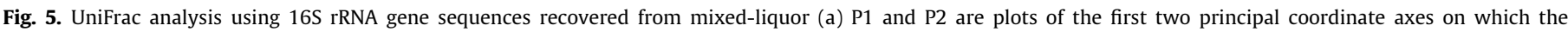

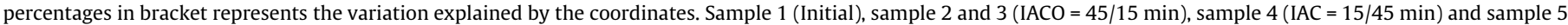

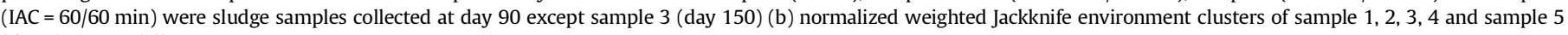
(description as (a)).

result clearly showed that the nitrifying (i.e. NOB) communities were sensitively responded to the DO concentration resulted from the different IACs. This finding was also consistent with the qPCR results that showed lower abundance (Fig. 4), and relatively poor $\mathrm{NH}_{4}-\mathrm{N}$ removal (Table 2) observed at 15/45 min of IAC. Depending on IACs, other seven phyla were also detected. Acidobacteria, Gemmatimonadates, Verrucomicrobia and Candidate division-OP10 were detected only at $\mathrm{IAC}_{\mathrm{O}}$ while Chlorobi, Candidate division-BRC1 and WCHB1-60 identified only at 15/45 min of IAC (Fig. 6a). Most phyla detected in the current study were also reported in previous studies carried on wastewater treatment systems (Liu et al., 2005; Cheng et al., 2008; Xia et al., 2010). The three dominant phyla which have been dominant here also found predominant in others. For example, Cheng et al. (2008) detected mainly Bacteroidetes followed by Proteobacteria, Firmicutes and Actinobacteria as dominant groups which together accounted for $93.1 \%$.
During various IACs, community shifts were observed among phyla and unclassified bacteria. Samples taken after 3 months (day 90) showed that the Proteobacteria increased from the initial $31 \%$ to $56 \%, 62 \%$ and $63 \%$ at the IACs of $15 / 45,45 / 15$ and 60/60 min, respectively (Fig. 6a). The increase of Proteobacteria with increasing the aeration ("on") cycle was accompanied by a decrease trend on the other phyla. For instance, Firmicutes decreased from the initial $26 \%$ to $18 \%$ and $4 \%$ at IACs of $15 / 45$ and $45 / 15 \mathrm{~min}$, respectively (Fig. 6a). The same decreasing trends were also observed in Bacteroidetes and unclassified bacteria. Moreover, compared 90th and 150th day sample that operated at the same $\mathrm{IAC}_{\mathrm{O}}$, an increased Proteobacteria percentage (83\%) were observed for the later sampling date which totally unfavorable for Firmicutes (undetected) and other phyla, implying longer operation time could favor a specific group of bacteria (i.e. Proteobacteria) (Fig. 6a). This result agrees with Sofia et al. (2004) investigation 

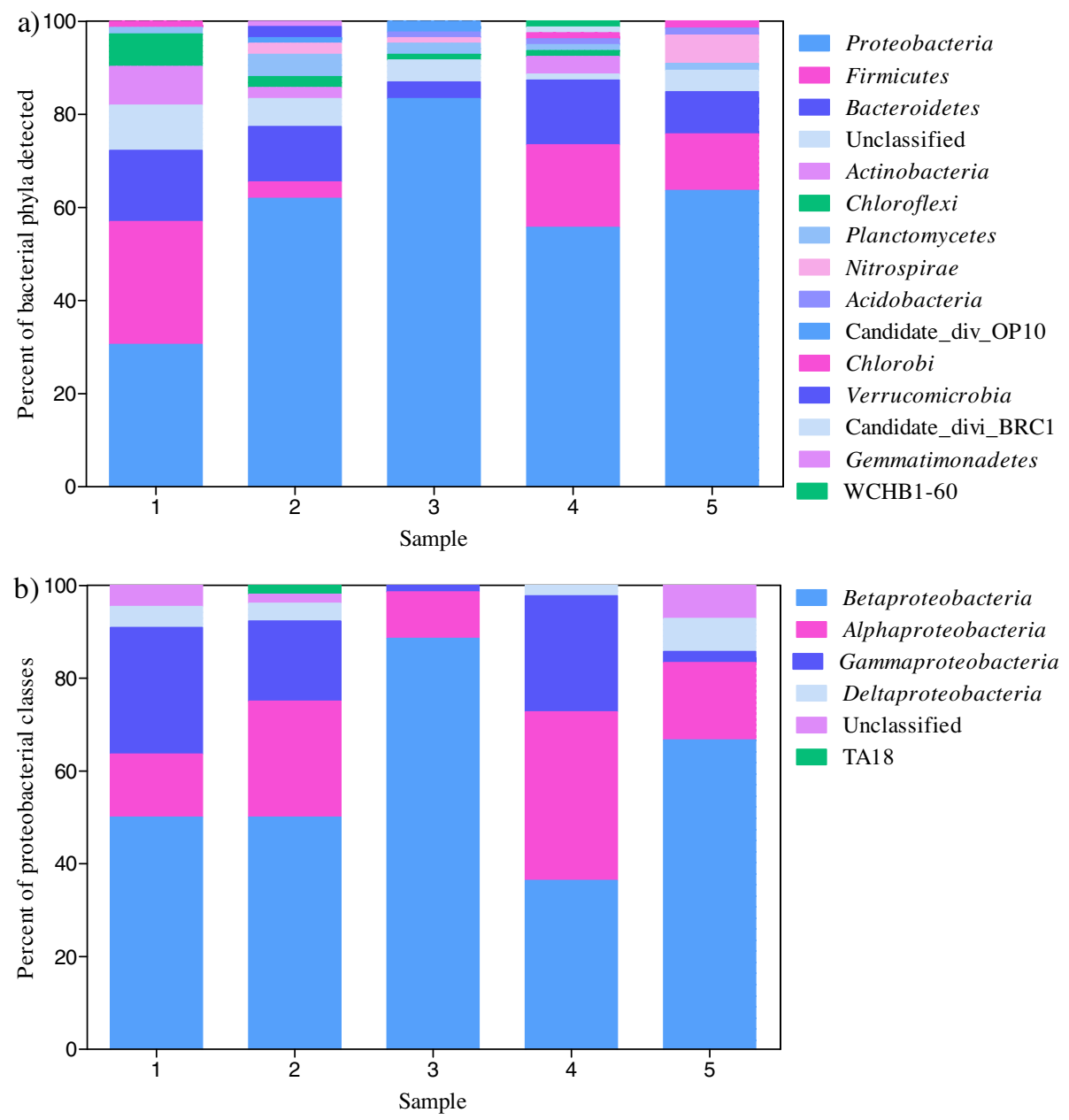

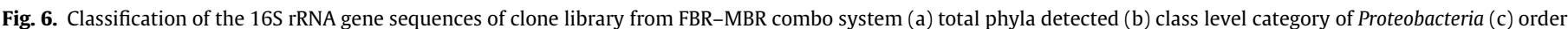

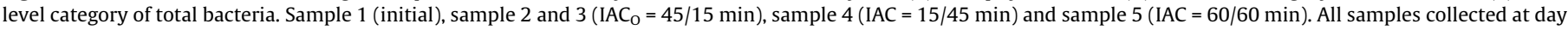
90 except sample 3 (day 150).

of microbial community in an $\mathrm{A} / \mathrm{O}$ submerged membrane bioreactor that observed a complete microbial population shift to Proteobacteria at long sludge age.

The community shifts observed among different phyla were also happened at class level on the same phylum. For example, within the predominant phylum Proteobacteria, the four major classes such as Alphaproteobacteria, Betaproteobacteria (dominant), Deltaproteobacteria and Gammaproteobacteria showed significant community shifts depending on aeration cycles (Fig. 6b). When the combo system operated at $\mathrm{IAC}_{\mathrm{O}}$, the Betaproteobacteria increased over time from $50 \%$ (day 90 ) to $88.6 \%$ (day 150), while the proportion of the other Proteobacteria classes decreased (Fig. 6b). The same trend of community dynamics were also observed when the combo system operated at IAC of 60/60 min. Comparing IACs of 45/15 min (day 90 and 150) and 60/60 min (day 90), more proportion of Betaproteobacteria community were observed for samples collected at day 150. The 90th day sample for both $45 / 15$ and $60 / 60 \mathrm{~min}$ of IACs exhibited almost proportional Proteobacteria population, indicating that DO level was not the limiting factor at these two operations for Proteobacteria rather the sludge age. This was consistent with the UniFrac results shown in Fig. 5. Furthermore, at shorter aeration cycle (IAC $=15 / 45 \mathrm{~min}$ ), the proportion of Betaprotobacteria and Alphaproteobacteria were equally dominant (36\%) followed by Gammaproteobacteria (25\%) and Delatprotobacteria (3\%).
In a more specific phylogenetic view, the total sequences were placed in 32 orders and some unclassified bacteria (Fig. 6c), among which 15 bacterial orders were affiliated to Proteobacteria (with $\geqslant 80 \%$ similarity) (Table S1). Burkholderiales and Rhodocyclales from Betaprotobacteria and Rhodospirillales and Rhizobiales from Alphaproteobacteria were detected from $3.4 \%$ to $18 \%$ of the total sequence orders (Fig. $6 \mathrm{c}$ and Table S1). Burkholderiales, the dominant order in this study (particularly sample 3), were previously identified in MBR system operated under aerobic-anaerobic condition (Sadaie et al., 2007), which indicate its metabolic flexibility. Members from Rhodocyclales, a purple non-sulfur photosynthetic bacteria, was identified as phosphate accumulating organism that use either oxygen or nitrate as final electron acceptor (Seviour et al., 2003). Members of the phylum Actinobacteria such as Acidimicrobidae and Actinobacteridae (Gram-positive bacteria with high DNA G $+C$ content) and Gemmatimonadales (97\% similarity with phylum Gemmatimonas) were detected in the current study also reported as a predominate group of bacteria in phosphateremoving activated sludge (Seviour et al., 2003; Liu et al., 2005) (Fig. 6c and Table S1). Interestingly, Pseudomonadales and Aeromonadales from Gammaproteobacteria group were detected in this study had also been previously reported denitrifying bacteria (Seviour et al., 2003; Sofia et al., 2004). The order Planctomycetales detected in the current study (Fig. 6c) was also identified as denitrifying bacteria which play anammox (anaerobic ammonia 


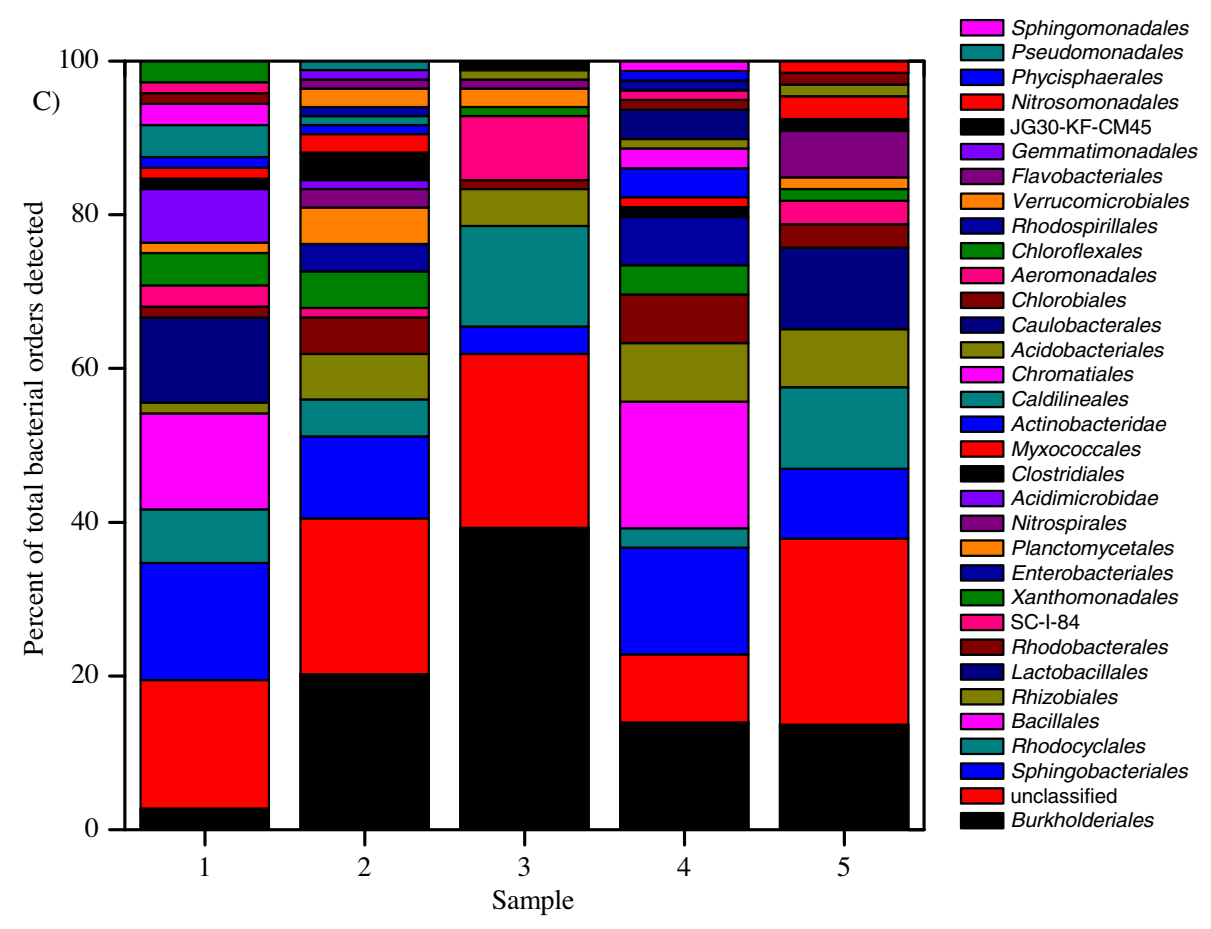

Fig. 6 (continued)

oxidation) activity under anoxic/anaerobic environment (Zhang et al., 2012). Moreover, Bacillales (low DNA G+C content and Gram-positive bacteria) from the phylum Firmicutes, were also detected (Fig. 6c) and identified previously as denitrifying bacteria (Sofia et al., 2004; Cheng et al., 2008). Nitrosomonadales (Betaproteobacteria) and Nitrospirales (Nitrospirae), which has been previously reported as the primary $\mathrm{AOB}$ and $\mathrm{NOB}$, respectively in wastewater treatment systems (Sofia et al., 2004; Ahmed, 2012) were identified here (Fig. 6c). In this study, the co-existence of nitrifying and denitrifying communities in a single reactor demonstrated that SND activities occurred in the combo system, which was also supported by the chemical analyses (Table 1). All Bacteroidetes related phylotypes were affiliated to the order Sphingobacteriales and Flavobacteriales which was consistent with others study (Cheng et al., 2008). The Sphingobacteriales groups were known for their interesting catabolic capabilities to degrade a wide variety of environmentally pollutants (Fig. 6c).

\section{Conclusions}

In this study, attempts have been made to relate the effect of IACs on nutrient removal and microbial community structure. At $I_{A C}$ (on/off $=45 / 15 \mathrm{~min}$ ), the combo system was able to achieve very good nutrient $\left(\mathrm{PO}_{4}-\mathrm{P}=92.3 \pm 4.1 \%\right.$ and $\left.\mathrm{NH}_{4}-\mathrm{N}=98.7 \pm 2.1 \%\right)$ and organic matter $(\mathrm{COD}=99.4 \pm 0.6 \%)$ removals. Particularly, phosphorus recovery in FBR as struvite is a unique sustainable feature of the combo system. The NE $(98.1 \pm 2.2)$ and SND activities $(82.8 \pm 11.7 \%)$ were also achieved due to the co-existence of diverse and stable microbial communities in MBR. The phylum Proteobacteria (59\%), Firmicutes (12\%) and Bacteroidetes (11\%) were the dominant bacterial groups, which showed shifts depending on IACs.

\section{Acknowledgements}

This work was supported by the National Science and Technology Pillar Program (2013BAD21B03), the Fundamental Research Funds for the Central Universities, Shanghai Shuguang Tracking Program
(No. 10GG12), NSFC (51378368) and 1st World Membrane Bioreactor (MBR) Centre.

\section{Appendix A. Supplementary data}

Supplementary data associated with this article can be found, in the online version, at http://dx.doi.org/10.1016/j.biortech.2014. 01.008 .

\section{References}

Adnan, A., Mavinic, D.S., Koch, F.A., 2003. Pilot-scale study of phosphorus recovery through struvite crystallization-examining the process feasibility. J. Environ. Eng. Sci. 2, 315-324.

Ahmed, Z., 2012. Microbial communities in nutrient-removing membrane bioreactor: a review. J. Environ. Sci. Technol. 5, 16-28.

Amann, R.I., Ludwig, W., Schleifer, K.H., 1995. Phylogenetic identification and in situ detection of individual microbial cells without cultivation. Microbiol. Rev. 59, 143-169.

APHA, Awwa, WEF, 1998. Standard Methods for the Examination of Water and Wastewater, 20th ed. American Public Health Association, Washington, DC.

Bellucci, M., Ofiteru, I.D., Graham, D.W., Head, I.M., Curtis, T.P., 2011. Low-dissolved oxygen nitrifying systems exploit ammonia-oxidizing bacteria with unusually high yields. Appl. Environ. Microbiol. 77, 7787-7796.

Campos, J.L., Garrido, J.M., Mosquera-Corral, A., Mendez, R., 2007. Stability of a nitrifying activated sludge reactor. Biochem. Eng. J. 35, 87-92.

Cheng, D., Zhenbin, W., Enrong, X., Qiaohong, Z., Shuiping, C., Wei, L., Feng, H., 2008. Bacterial diversity in activated sludge from a consecutively aerated submerged membrane bioreactor treating domestic wastewater. J. Environ. Sci. 20, 12101217.

Dionisi, H.M., Harms, G., Layton, A.C., Gregory, I.R., Parker, J., Hawkins, S.A., Robinson, K.G., Sayler, G.S., 2003. Power analysis for real-time PCR quantification of genes in activated sludge and analysis of the variability introduced by DNA extraction. Appl. Environ. Microbiol. 69, 6597-6604.

Duan, L., Moreno-Andrade, I., Huang, C.L., Xia, S., Hermanowicz, S.W., 2009. Effects of short solids retention time on microbial community in a membrane bioreactor. Bioresour. Technol. 100, 3489-3496.

Dubois, M., Gilles, K.A., Hamilton, J.K., Rebers, P.A., Smith, F., 1956. Colorimetric method for determination of sugars and related substances. Anal. Chem. 28, 350-356.

Feng, W., Si-qing, X., Yi, L., Xue-song, C., Jun, Z., 2007. Community analysis of ammonia and nitrite oxidizers in start-up of aerobic granular sludge reactor. J. Environ. Sci. 19, 996-1002.

Guadie, A., Xia, S., Jiang, W., Zhou, L., Zhang, Z., Hermanowicz, S.W., Xu, X., Shen, S., in press. Enhanced struvite recovery from wastewater using a novel 
cone-inserted fluidized bed reactor. J. Environ. Sci. http://dx.doi.org/10.1016/ S1001-0742(13)60469-6.

Guadie, A., Xia, S., Zhang, Z., Guo, W., Ngo, H.H., Hermanowicz, S.W., 2013b. Simultaneous removal of phosphorus and nitrogen from sewage using a novel combo system of fluidized bed reactor-membrane bioreactor (FBR-MBR). Bioresour. Technol. 149, 276-285.

Guo, W., Ngo, H.H., Palmer, C.G., Xing, W., Hu, A.Y.J., Listowski, A., 2009. Roles of sponge sizes and membrane types in a single stage sponge-submerged membrane bioreactor for improving nutrient removal from wastewater for reuse. Desalination 249, 672-676.

Huang, L., Ju, L.K., 2007. Sludge settling and online NAD(P)H fluorescence profiles in wastewater treatment bioreactors operated at low dissolved oxygen concentrations. Water Res. 41, 1877-1884.

Kornboonraksa, T., Lee, H.S., Lee, S.H., Chiemchaisri, C., 2009. Application of chemical precipitation and membrane bioreactor hybrid process for piggery wastewater treatment. Bioresour. Technol. 100, 1963-1968.

Le Corre, K.S., Valsami-Jones, E., Hobbs, P., Parsons, S.A., 2007. Impact of reactor operation on success of struvite precipitation from synthetic liquors. Environ. Technol. 28, 1245-1256.

Liu, Y., Zhang, T., Fang, H.H., 2005. Microbial community analysis and performance of a phosphate-removing activated sludge. Bioresour. Technol. 96, 1205-1214.

Liu, Z., Zhao, Q., Lee, D.J., Yang, N., 2008. Enhancing phosphorus recovery by a new internal recycle seeding MAP reactor. Bioresour. Technol. 99, 6488-6493.

Lowry, O.H., Rosebrough, N.J., Farr, A.L., Randall, R.J., 1951. Protein measurement with the folin phenol reagent. J. Biol. Chem. 193, 265-275.

Lozupone, C., Knight, R., 2005. UniFrac: a new phylogenetic method for comparing microbial communities. Appl. Environ. Microbiol. 71, 8228-8235.

Masse, A., Sperandio, M., Cabassud, C., 2006. Comparison of sludge characteristics and performance of a submerged membrane bioreactor and an activated sludge process at high solids retention time. Water Res. 40, 2405-2415.

Rong, Q., Kun, Y., Zhao-xiang, Y., 2007. Treatment of coke plant wastewater by SND fixed biofilm hybrid system. J. Environ. Sci. 19, 153-159.

Ruiz, G., Jeison, D., Chamy, R., 2003. Nitrification with high nitrite accumulation for the treatment of wastewater with high ammonia concentration. Water Res. 37, 1371-1377.
Sadaie, T., Sadaie, A., Takada, M., Hamano, K., Ohnishi, J., Ohta, N., Matsumoto, K., Sadaie, Y., 2007. Reducing sludge production and the domination of comamonadaceae by reducing the oxygen supply in the wastewater treatment procedure of a food-processing factory. Biosci. Biotechnol. Biochem. 71, 791-799.

Schloss, P.D., Westcott, S.L., Ryabin, T., Hall, J.R., Hartmann, M., Hollister, E.B., Lesniewski, R.A., Oakley, B.B., Parks, D.H., Robinson, C.J., Sahl, J.W., Stres, B., Thallinger, G.G., Van Horn, D.J., Weber, C.F., 2009. Introducing mothur: opensource, platform-independent, community-supported software for describing and comparing microbial communities. Appl. Environ. Microbiol. 75, 75377541.

Seviour, R.J. Mino, T. Onuki, M., 2003. The microbiology of biological phosphorus removal in activated sludge systems. FEMS Microbiol. Rev. 27, 99-127.

Shu, L., Schneider, P., Jegatheesan, V., Johnson, J., 2006. An economic evaluation of phosphorus recovery as struvite from digester supernatant. Bioresour. Technol. 97, 2211-2216.

Sofia, A., Liu, W.T., Ong, S.L., Ng, W.J., 2004. In-situ characterization of microbial community in an $\mathrm{A} / \mathrm{O}$ submerged membrane bioreactor with nitrogen removal. Water Sci. Technol. 50, 41-48.

Third, K.A., Burnett, N., Cord-Ruwisch, R., 2003. Simultaneous nitrification and denitrification using stored substrate (phb) as the electron donor in an SBR. Biotechnol. Bioeng. 83, 706-720.

Wang, B., Wang, W., Han, H., Hu, H., Zhuang, H., 2012. Nitrogen removal and simultaneous nitrification and denitrification in a fluidized bed step-feed process. J. Environ. Sci. 24, 303-308.

Wittebolle, L, Verstraete, W., Boon, N.,2009. The inoculum effect on the ammoniaoxidizing bacterial communities in parallel sequential batch reactors. Water Res. 43, 4149-4158.

Xia, S., Li, J., He, S., Xie, K., Wang, X., Zhang, Y., Duan, L., Zhang, Z., 2010. The effect of organic loading on bacterial community composition of membrane biofilms in a submerged polyvinyl chloride membrane bioreactor. Bioresour. Technol. 101, 6601-6609.

Zhang, Z., Li, Y., Chen, S., Wang S., Bao, X, 2012. Simultaneous nitrogen and carbon removal from swine digester liquor by the Canon process and denitrification. Bioresour. Technol. 114, 84-89. 